\title{
Russian centre on the map of the martial arts tourism - Congress and festival in Saint Petersburg, Russia
}

\author{
Wojciech J. CYNARSKI* \\ Faculty of Physical Education, University of Rzeszow (Poland)
}

Recepción: 31/10/2017; Aceptación: 14/02/2018; Publicación: 16/02/2018.

\begin{abstract}
This report informs on the VIII International Congress "Sport, People and Health", held in Saint Petersburg between October 12 and 14, 2017, from the perspective of scientific tourism and martial arts tourism. We used qualitative methods (single-case study and participant observation) in doing the report, including descriptive, interpretative and evaluative contents. The congress gathered more than 600 participants. Martial arts and combat sports were a key content, with a total of 33 works presented on the topic, and also it was possible to attend martial arts and combat sports demonstrations. We conclude that this event was a good example of scientific and martial arts tourism and of the increasing willingness of Russian academics to participate in the international community of martial arts and combat sports researchers. Some suggestions for increasing the scientific impact of the event are provided.

Keywords: Martial arts; combat sports; sambo; scientific tourism; martial arts tourism; scientific events; institutionalisation.

\section{Institución rusa en el mapa del turismo marcial - Congreso y festival en San Petersburgo, Rusia \\ Resumen}

Este trabajo informa del VIII International Congress "Sport, People and Health", celebrado en San Petersburgo entre los días 12 y 14 de octubre de 2017, desde la perspectiva del turismo científico y del turismo de artes marciales. Para la realización del informe hemos utilizado métodos cualitativos (estudio de caso y observación participante), incluyendo contenidos descriptivos, interpretativos y evaluativos. El congreso reunió a más de 600 participantes. Las artes marciales y los deportes de combate fueron un contenido clave del congreso, con un total de 33 trabajos presentados sobre la temática, y también fue posible asistir a demostraciones de artes marciales y deportes de combate. Concluimos que este evento fue un buen ejemplo de turismo científico y de artes marciales, así como la creciente voluntad de los académicos rusos de participar en la comunidad internacional de investigadores en artes marciales y deportes de combate. También se realizan algunas sugerencias para incrementar el impacto científico de este evento.

Palabras clave: Artes marciales; deportes de combate; sambo; turismo científico; turismo de artes marciales; eventos científicos; institucionalización.

\section{Instituição russa e o mapa do turismo marcial - Congresso e festival em São Petersburgo, Rússia} Resumo

Este trabalho informa sobre o VIII Congresso Internacional "Sport, People and Health", que ocorreu em São Petersburgo, entre os dias 12 e 17 de outubro de 2017. Apresenta a perspetiva do turismo científico e do turismo das artes marciais. Para sua realização, utilizámos métodos qualitativos (estudo do caso e observação participante), incluindo conteúdos descritivos, interpretativos e avaliativos. 0 congresso reuniu mais de 600 participantes. As artes marciais e os desportos de combate foram um tema chave do congresso, com um total de 33 trabalhos apresentados sobre a temática. Foi possível também assistir a demonstrações de artes marciais e desportos de combate. Concluímos que este evento foi um bom exemplo de turismo científico e de artes marciais, assim como a crescente vontade dos académicos russos em participar na comunidade internacional de investigadores de martes marciais e desportos de combate. Realizam-se, igualmente, sugestões para incrementar o impacto científico deste evento.

Palavras-chave: Artes marciais; desportos de combate; sambo; turismo científico; turismo de artes marciais; eventos científicos; institucionalização.
\end{abstract}

\section{Introduction}

In martial arts anthropology, spatial mobility is part of the lifestyle of martial artists (Cynarski, 2012). So, for example, Chinese martial artists try to practice at the source, i.e., in China, supporters of Japanese varieties practice in Japan, etc.

\footnotetext{
*E-mail: cynarski@ur.edu.pl
} 
Geography of martial arts creates its maps. These include countries and places of the origin of martial arts (cf. Obodynski, Cynarski, \& Litwiniuk, 2005; Shahar, 2008; Cynarski \& Swider, 2017), as well as today's centres of their functioning (Miller Griffith, 2010; Raimondo, 2011; Cynarski, 2017a). These centres are where the best teachers teach, or other factors decide.

The problem (given in the title) discussed here is the perspective of scientific tourism (Cynarski, 2015) and tourism of martial arts (Cynarski \& Duricek, 2014). Both forms of tourism are treated here as a form of cultural tourism, the foundations are found in cultural anthropology (Salazar \& Graburn, 2014; Munsters \& Melkert, 2015). This is especially true of the tourist's desire to meet self-realization needs. Self-realization motives and values-goals dominate over the pursuit of entertainment and pleasure (Cynarski, 2017b).

The first qualitative method used here is the single case study research. This is descriptive, interpretive, and evaluative (Skinner, Edwards, \& Corbett, 2015: 116-133). The second qualitative method is participant observation (cf. Spencer, 2012: 166-168).

We can talk about institutionalization in the field of organizations that deal with both martial arts practice and martial arts research (Cynarski \& Kubala, 2015). There are already specialized organizations such as IMACSSS (the International Martial Arts and Combat Sports Scientific Society) (see e.g., Brizin, 2015; Vertonghen, 2012). Conferences and congresses are organized periodically, and scientific organizations are set up by sports organizations.

The former Soviet Union and the present-day Russian Federation are the founding countries of sambo - the sport of fighting, self-defence and military combat (Andriejev \& Tschumakov, 1976; Blach, Cynarski, \& Blach, 2006). The sportive version of sambo is already being taught in many countries around the world and the leaders of the International Sambo Federation (FIAS) are seeking an Olympic nomination for this discipline. The latter was probably one of the aims of the 2017 Saint Petersburg Congress, entitled VIII International Congress "Sport, People and Health".

\section{Preparation and travel}

The Saint Petersburg Congress was scheduled for October 12-14, 2017. The organizers were the International Public Organization for Promotion of Science and Sport "Sport, People, Health" (from Saint Petersburg, Russian Federation), the Lesgaft National State University of Physical Education, Sport and Health (also Saint Petersburg, Russian Federation), and the International SAMBO Federation (FIAS). Other patrons included the Ministry of Sport of the Russian Federation, the Russian Olympic Committee, Governor of Saint Petersburg, Governor of Leningrad Gubernia, Lesgaft University and State University of Saint Petersburg, Military University of Kirov Medical School, the Council of Europe, and UNESCO.

Despite all this official support, an unexpected difficulty for people from European countries was obtaining a Russian visa. Perhaps that is why few Poles are currently travelling to Russia. Despite the invitation to a scientific conference, a tourist visa was required, and the procedure was more complicated than the visas of many other countries (all known to the author).

Nonetheless, Saint Petersburg turned out to be a hospitable city. One can see the museum ship Aurora, which served in the Russo-Japanese War of 1904-1905 and later fired some of the first shots in the Bolshevik revolution of 1917. One can learn about the 872-day defence of the besieged Leningrad during the Great Patriotic War of 1941-1945. If one prefers art, there is the magnificent State Hermitage Museum (Spalle, 1976: 15-18). For learning, there is the University of Lesgaft. And for simple scenery, there are white nights, and a panoramic view of the Radisson Hotel "Pribaltiyskaya".

\section{Programme of the Congress}

The theme of the congress was Unity of the Olympic Movement and preservation of ethical values of the world sports. According to Grishin's (2017) report, more than 600 participants (scientists, presidents of international sports federations, representatives of international sports organisations, outstanding athletes, veterans of sports, public figures) from more than 40 countries 
participated in the congress. The official languages for the congress were Russian and English. Also simultaneous translation was used for all congress.

On October 12, the Congress was opened. The proceedings took place at the main hall of the Hotel Radisson "Pribaltiyskaya". The main organisers introduced themselves: Mr Vasily Shestakov, President FIAS, Prof. Vladimir Taymazov (Chairman of the Scientific Committee) and Prof. Sergey Bakulev (Rector of the Lesgaft University).

In the first Plenary Session (Picture 1) speakers included Prof. V.N. Platonov from Ukraine (about doping), Dr Schaefer (on ICSSPE), Mr Christofer Samuda (about physical health). There was a film on the International Military Sports Council (CISM), which featured the cooperation of this organization with North Korea. Afterwards. Visitors were taken on a tour of the famous Heritage Museum.

On October 13, the deliberations took place in thematic sections. Perhaps the most interesting were workshops and shows. Here the military group - рукопашный бой (hand-to-hand combat) and sports jujutsu presented their methods at the highest level. There were also sambo and martial arts show of children - forms with traditional weapons (cold steel, nunchaku, etc.).

On October 14, at the Final Plenary Session, nine papers were presented. The talks were led by Prof. Dr S.M. Ashkinazi. An interesting lecture was given by Dr Tatiana Iancheva (Bulgaria) on Cope with success in sport. The last two papers were presented by the IMACSSS president (Picture 2; Cynarski, 2017c, d). Full texts appear in a conference book called Proceedings Book (502 pages) (Taymazov et al., 2017).

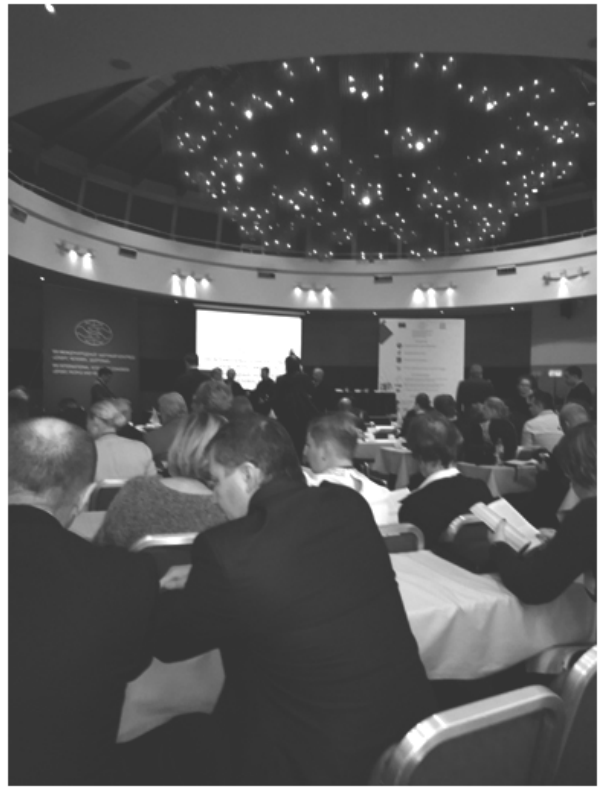

Picture 1. The first plenary session (courtesy of Dr K. Kubala)

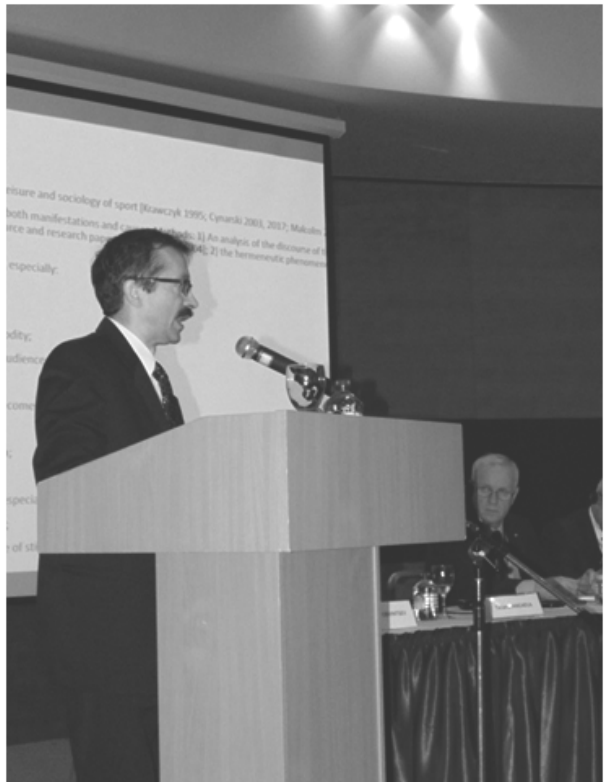

Picture 2. Plenary lecture of Prof. W.J. Cynarski (courtesy of Dr K. Kubala)

There were plenary sessions but also parallel sessions, which participants had to choose according to their interests. The congress was mostly in Russian (with the translation). According to the Programme, there were presented 33 works regarding martial arts and combat sports, mostly in Russian. The main topics presented on martial arts and combat sports were about judo and sambo treated interdisciplinary - various aspects and methodological approaches. Participants had possibilities for free interaction during coffee breaks and dinners.

\section{20 $^{\text {th }}$ International Festival of Martial Arts "Baltic Sea Cup"; Saint Petersburg, October 14- 15,2017}

After the closing of the VIII International Scientific Congress, there were visits to various sports facilities. On the turn of the Sibur Arena, there was a chance to see the opening ceremony of 
the 20th Martial Arts Festival "Baltic Sea Cup". There were military (melee combat), sambo, taekwondo, hapkido, karate, judo and a group of kung-fu wushu in silk, colourful, shiny costumes. The program included three orchestras and a ballet, and of course Russian flags and a hymn. The twentieth festival shows already a certain institutional maturity and tradition, and Saint Petersburg has become a significant centre of martial arts in Russia. Also, the two-year cycle of the Congress, the eighth edition of which is shown above, points to some organisational advancement.

\section{Reflections}

Despite the title of ethics of sport in the topic, the focus in the congress was on the area of martial arts and combat sports. The published proceedings and papers "cover a wide range of issues dealing with martial arts and combat sports and their role in the development of the world sports" (Taymazov et al., 2017: IV). It is worth noting that the links were made between physical education, sport, and health that linked to military training, and there were many representatives of uniformed services. The utilitarian use of martial arts and combat sports was also emphasized, including the educational uses of sambo.

Russia is still a force in martial arts, such as boxing, judo, and wrestling, and in Russia, instruction is generally carried out under the supervision of the Ministry of Defence. Russia is also the birthplace of sambo, and the rivalry with the Soviet "working and defending" badge is still present in the Russian school. Culturally, sambo was promoted as comparable to wushu and Shaolin quan-fa in China, budo in Japan, taekwondo in Korea, and Muai Thai in Thailand (Obodynski, Cynarski, \& Litwiniuk, 2005; Gomaratut, 2011; Cynarski, 2017b; Cynarski \& Swider, 2017). Sambo was also presented, although in smaller scale, as a Russian export commodity.

The emphasis on military and sport caused one to think about how one approaches one's own arts. From a liberal-left perspective, the military culture is unequivocally condemned (Lipiec, 2001). In the Humanist Theory of Martial Arts and anthropology of martial arts, the noble warrior's path from the "anti-way" is distinguished. "Anti-way" is a cult of strength. If a given military culture is linked to the policy of neo-imperial aggression, it is the "anti-way" emanation. Today, humanised budo is an expression of security culture for the $21^{\text {st }}$ century civilization (Cynarski \& Piwowarski, 2016). This "budo culture" can indeed constitute an antidote to the pathology of sport and various areas of physical culture (Cynarski, 2017c).

Similarly, combining two events (Congress and Festival), is an example of combining practical and research studies in Martial Arts and Combat Sports (MA / CS) and related tourism (cf. Pawelec, Slopecki, Sieber, \& Rut, 2015; Cynarski \& Kubala, 2017). It is a scientific tourism, to attend a conference, even if it is thematically related with one's interest or area of MA / CS.

According to some researchers, going to a scientific conference is a manifestation of business tourism (Sawicki, 2016). However, participating in such a conference does not result from working at a university. Two thirds of the participants from Poland drove to the described Congress to Saint Petersburg at their own expense, without the official delegation - for self-fulfilment.

The progressive integration of the international MA / CS research community is a positive one. It is good that institutions from China, Japan and Russia open up to this broader cooperation. Institutional development follows in the form of a calendar of cyclical events, maps of the most active centres, knowledge exchange platforms, etc. It may be a pity that the published volume of texts (Taymazov et al., 2017) contains most of the works published in Russian, which means it will be indexed only in some Russian scientific index.

\section{Conclusion}

It was established that the Congress (and the Festival) discussed here represents a specific type of conference which allows for a gathering of martial arts and combat sports experts, but one based on strictly scientific debate and observation of demonstrations. The Congress also had significant importance as a signal of the introduction of Russian researchers to the international society in the area of martial arts and combat sports. 
The proceedings were published mostly in Russian, and it was similarly in the Congress. What could be made for an increasing a scientific impact of this event? For an international audience organizers should publish all texts in English, or at least their abstracts, and submit it to an international index (as Web of Science, Scopus), and making them fully available on-line.

\section{Acknowledgements}

The author would like to thank Mr Joseph Svinth for linguistic correction of the manuscript.

\section{References}

Andriejev, V.M., \& Tschumakov, E.M. (1976). Sambo - Kampf. (2nd edn.) Berlin: Weinmann [in German].

Blach, W., Cynarski, W.J., \& Blach, L. (2006). Sambo - system samoobrony i sport. Ido - Ruch dla Kultury / Movement for Culture, 6, 100-103 [in Polish].

Brizin, D. (2015). Report on the third International Martial Arts and Combat Sports Scientific Society (IMACSSS) Conference. Revista de Artes Marciales Asiáticas, 10(1), 68-71. doi: $10.18002 /$ rama.v10i1.1597

Cynarski, W.J. (2012). Anthropology of Martial Arts. Studies and Essays of the Sociology and Philosophy of Martial Arts. Rzeszow: Rzeszow University Press [in Polish].

Cynarski W.J., (2015). Turystyka naukowa w perspektywie socjologii wizualnej. Rzeszów: Katedra Kulturowych Podstaw Wychowania Fizycznego, Turystyki i Rekreacji WWF UR.

Cynarski, W.J. (2017a). A cyclical meeting of experts as a special case of martial arts tourism. Ido Movement for Culture. Journal of Martial Arts Anthropology 17(3), 31-37. doi: 10.14589/ido.17.3.4

Cynarski, W.J. (2017b). Between Prague and Muju. A contribution to non-entertainment tourism research. Ido Movement for Culture. Journal of Martial Arts Anthropology 17(4), 37-43. doi: 10.14589/ido.17.4.7

Cynarski, W.J. (2017c). Ethical ways and anti-ways of sport: some examples. In V.A. Taymazov et al. (Eds.), VIII International Congress "Sport, People and Health" 12-14 October 2017 (pp. 1-3), Saint Petersburg, Russia.

Cynarski, W.J. (2017d). Sports pathologies in the 21 century: attempt at categorization. In V.A. Taymazov et al. (Eds.), VIII International Congress "Sport, People and Health" 12-14 October 2017 (pp. 3-7), Saint Petersburg, Russia.

Cynarski, W.J., \& Duricek, M. (2014). Scientific tourism. Self-realisation, dialogue-cultural and sacral dimensions. Ido Movement for Culture. Journal of Martial Arts Anthropology 14(4), 39-45. doi: $10.14589 /$ ido.14.4.5

Cynarski, W.J., \& Kubala, K. (2015). Scientific travel to Brno: the next step toward institutionalisation of martial arts research groups. Scientific Review of Physical Culture 5(4), 290-295.

Cynarski, W.J., \& Kubala, K. (2017). Congress in Rio Maior: the particular example of martial arts tourism and scientific tourism. Ido Movement for Culture. Journal of Martial Arts Anthropology 17(2), 34-40; doi: 10.14589/ido.17.2.4

Cynarski, W.J., \& Piwowarski, J. (2016). Japanese security culture in the global village. The Budo Charter as a modernized element of ancient military tradition. Security Dimensions. International and National Studies 20, 30-50. doi: 10.24356/SD/20/1

Cynarski, W.J., Swider, P. (2017). The journey to the cradle of martial arts: a case study of martial arts' tourism. Ido Movement for Culture. Journal of Martial Arts Anthropology 17(2), 24-33. doi: $10.14589 /$ ido.17.2.3

Gomaratut C. (2011). Muai-Thai: The art and science of Thai traditional self defense. In W.J. Cynarski (Ed.), Selected Areas of Intercultural Dialogue in Martial Arts (pp. 123-136). Rzeszow: Rzeszow University Press.

Grishin, S. (2017). The VIII International Scientific Congress “Sport, People, Health” 2017. Retrieved from http://sambo-fias.org/en/news/viii-mezhdunarodnyy-nauchnyy-kongress-sportchelovek-zdorove/ 
Lipiec, J. (2001). Świat wartości. Wprowadzenie do aksjologii. Kraków: FALL [in Polish].

Miller Griffith, L. (2010). Martial arts tourism. In T.A. Green, \& J.R. Svinth (Eds.), Martial Arts in the World: An Encyclopedia of History and Innovation (pp. 411-415). Santa Barbara (CA): ABCClio.

Munsters, W., \& Melkert, M. (Eds.) (2015). Anthropology as a Driver for Tourism Research. Antwerpen - Apeldoorn: Garant.

Obodynski, K., Cynarski, W.J., \& Litwiniuk, A. (2005), Self-educational tourism on the way of Budō. In K. Obodynski, \& W.J. Cynarski (Eds.), International Dialogue: Global, European, National and Multicultural Dimensions of Tourism (pp. 165-181), Rzeszow: European Academy for the Carpathian Euroregion.

Pawelec, P., Slopecki, J., Sieber, L., \& Rut, P. (2015). Scientific and martial arts' tourism. The case study of the 3rd IMACSSS International Conference and Congress. Ido Movement for Culture. Journal of Martial Arts Anthropology 15(1), 46-56. doi: 10.14589/ido.15.1.7

Raimondo, S. (2011). Heritage tourism and Taijiquan. The case of Chenjiagou, Henan, RPC. Ido Movement for Culture. Journal of Martial Arts Anthropology, 11(1), 52-59.

Salazar, N.B., \& Graburn, N.H.H. (Eds.) (2014). Tourism Imaginaries. Anthropological Approaches. New York - Oxford: Berghahn.

Sawicki, B. (2016), Reflections on business tourism in the context of the monograph study "Science tourism from a visual sociology perspective". Ido Movement for Culture. Journal of Martial Arts Anthropology 16(4), 42-46. doi: 10.14589/ido.16.4.8

Shahar, M. (2008). The Shaolin Monastery. History, Religion, and the Chinese Martial Arts. Honolulu: University of Hawai'i Press.

Skinner, J., Edwards, A., \& Corbett, B. (2015), Research methods for sport management. London New York: Routledge.

Spalle, S. (1976). ZSRR. Informator turystyczny. Warsaw: KAW [in Polish].

Spencer, D.C. (2012). Ultimate fighting and embodiment. Violence, gender, and Mixed Martial Arts. New York: Routledge.

Taymazov V.A., Ashkinazi S.M., Bakulev S.E., Buchel M., Bulatova M.M., Cynarski W.J. ... Zakrevskaya N.G. (Eds.) (2017), VIII International Congress "Sport, People and Health" 12-14 October 2017, Saint Petersburg, Russia.

Vertonghen, J. (2012). Report on the first International Martial Arts and Combat Sports Scientific Society (IMACSSS) Conference - "Game, Drama, Ritual in Martial Arts and Combat Sports". Revista de Artes Marciales Asiáticas, 7(1), 44-47. doi: 10.18002/rama.v7i1.422

\section{Author's biographical data}

Prof. Dr. Cynarski, full-professor, working at Rzeszów University (Poland), and Head of the Chair of Cultural Foundation for PE, Tourism and Recreation. He has master's degrees in sociology and technical sciences, has carried out post-graduate studies in pedagogy, and has a doctorate and qualifications in the sciences of physical culture (University of Physical Education in Warsaw). He is the founder and president (since 1993) of the Idokan Poland Association, president of IMACSSS, and the editor-in-chief of "Ido Movement for Culture. Journal of Martial Arts Anthropology". He has been practicing martial arts since 1977. Currently he has the title Kaiden Shihan (Menkyo Kaiden) in the Idokan Yoshin-ryu, and is 9th-dan jujutsu, 8th-dan karate, 7thdan aikijutsu, 6th-dan iaido, and 6rd-dan kobudo. E-mail: cynarski@ur.edu.pl 